\title{
Neuroinflammation: A Signature or a Cause of Epilepsy?
}

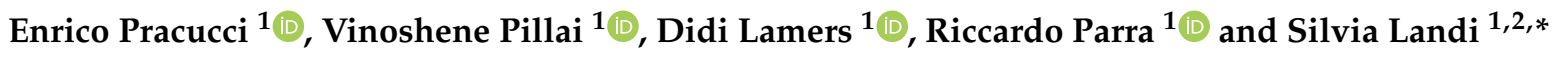 \\ 1 National Enterprise for Nanoscience and Nanotechnology (NEST), Istituto Nanoscienze Consiglio Nazionale \\ delle Ricerche (CNR) and Scuola Normale Superiore Pisa, 56127 Pisa, Italy; enrico.pracucci@sns.it (E.P.); \\ vinoshene.pillai@sns.it (V.P.); didi.lamers@ru.nl (D.L.); riccardo.parra@gmail.com (R.P.) \\ 2 Institute of Neuroscience CNR, 56127 Pisa, Italy \\ * Correspondence: silvia.landi@in.cnr.it
}

Citation: Pracucci, E.; Pillai, V.;

Lamers, D.; Parra, R.; Landi, S. Neuroinflammation: A Signature or a Cause of Epilepsy? Int. J. Mol. Sci. 2021, 22, 6981. https://doi.org/ $10.3390 /$ ijms 22136981

Academic Editor: Georgia Mandolesi

Received: 12 April 2021

Accepted: 23 June 2021

Published: 29 June 2021

Publisher's Note: MDPI stays neutral with regard to jurisdictional claims in published maps and institutional affiliations.

Copyright: (c) 2021 by the authors. Licensee MDPI, Basel, Switzerland. This article is an open access article distributed under the terms and conditions of the Creative Commons Attribution (CC BY) license (https:/ / creativecommons.org/licenses/by/ $4.0 /)$.

\begin{abstract}
Epilepsy can be both a primary pathology and a secondary effect of many neurological conditions. Many papers show that neuroinflammation is a product of epilepsy, and that in pathological conditions characterized by neuroinflammation, there is a higher probability to develop epilepsy. However, the bidirectional mechanism of the reciprocal interaction between epilepsy and neuroinflammation remains to be fully understood. Here, we attempt to explore and discuss the relationship between epilepsy and inflammation in some paradigmatic neurological and systemic disorders associated with epilepsy. In particular, we have chosen one representative form of epilepsy for each one of its actual known etiologies. A better understanding of the mechanistic link between neuroinflammation and epilepsy would be important to improve subject-based therapies, both for prophylaxis and for the treatment of epilepsy.
\end{abstract}

Keywords: epilepsy; neuroinflammation; brain excitability

\section{Introduction}

Neuroinflammation is the process of inflammation that involves nervous tissues, and it can be originated by several exogenous or endogenous factors [1-3]. Several factors can activate neuroinflammation, such as infection, traumatic brain injury, toxic metabolites, autoimmune diseases, aging, air pollution, passive smoke or spinal cord injury, and stimulate the production of cytokines and chemokines, which also act as a support for cell growth and survival. They include at least 40 types of interleukins (IL), first thought to be expressed only by leukocytes, but later found to be produced by different cell types [4]. Cytokines and chemokines activate microglia, as a primary immune response in the central nervous system (CNS). Continuous microglia activation causes the recruitment of peripheral immune cells [5], such as macrophages and B and T lymphocytes, which are responsible for the innate and adaptive immune response. These immune cells can access the brain through a compromised blood brain barrier (BBB), amplifying the defense mechanism and bringing about widespread chronic inflammation, and possibly neurodegenerative effects [6]. Another cellular component activated during neuroinflammation is represented by astrocytes; they are strictly linked to the BBB structure and can be responsive to signals released by injured neurons or activated microglia. Their contribution to tissue repair can be substantial, as in the case of glial scar formation, which is retained to promote axonal regeneration [1]. However, prolonged chronic insults can favor the activation of molecular pathways that sustain the inflammatory properties from brain-resident cells, causing a maladaptive response that can be harmful to the CNS [7].

Many studies have explored the interaction between neuroinflammation and neurological disorders, particularly with epilepsy [7,8]. Epilepsy can be a primary pathology, due to structural or genetic reasons, or a secondary effect. In the latter case, it can be a consequence of traumatic brain injuries and brain tumors; then, it can be related to an infectious, metabolic, immune or unknown etiology, as summarized in the last ILAE classification 
of the epilepsies [9]. Undoubtedly, the presence of certain chronic inflammatory diseases facilitates epilepsy or other neurological manifestations. Indeed, in most autoimmune diseases, there is a five-fold increased risk of epilepsy in children and a four-fold increased risk in non-elderly adults (aged < 65) [10,11]. Even though the impaired regulation of the inflammatory response in injured neuronal tissue is a critical factor to the development of epilepsy, it is still unclear how this unbalanced regulation of inflammation contributes to epilepsy [8]. On the other hand, several studies have shown that epileptogenesis produces long-term effects on neuroinflammation, worsening the progression and outcome of epilepsy [7,8,12-14].

In these last years, common pathways relating epilepsy to neuroinflammation have been identified, starting from the pioneering study of Goddard [14-17]. Interestingly, different models of chemically and electrically induced seizures show upregulation of genes expressed in inflammatory cascades, as seen in patients [18]. In epileptic rodent models, a key role is played by IL- $1 \beta$, its receptor (IL-1R), and the antagonist of its receptor (IL-1Ra) [18-19-20-21-22-44]. Epileptogenesis, as well as several other conditions that bring about secondary epileptic phenotype [19-21], is also correlated to the activation of Toll-like receptors (TLRs). Indeed, TLRs are responsible for the innate immune response, as factors upstream of IL- $1 \beta$. Once a pathogen enters the organism, transmembrane receptors that are especially present on the membrane of macrophage and dendritic cells, recognizes it, and triggers localized inflammation. Moreover, various hyperacetylated molecules, such as "high-mobility box 1 group protein" (HMGB), a chromatin component released during necrosis, are capable to amplify TLRs activation [22], and are involved in ictogenesis in models of chronic epilepsy and in humans [23]. Further factors are tumor necrosis factor- alfa (TNF- $\alpha$ ), transforming growth factor beta (TGF- $\beta$ ), cyclo-oxygenase 2, and thrombospondin (TSP-1) [24]. Recently, the pentraxin family (PTXs) has also been identified to be involved in the immune response promoting epilepsy. PTX3 is expressed in the brain, where it is secreted by several white blood cells in response to inflammatory signals [25]. It interacts with the extracellular matrix and participates in remodeling AMPA receptors, regulating circuit excitability. PTX3 activation has been shown to have a pivotal role in a mouse model of experimental autoimmune encephalitis [26]. Then, it has been shown that the upregulation of inflammation causes effects at the extracellular matrix level, increasing levels of the redox-sensitive matrix metalloproteinase MMP-9 inside the epileptic brain [27] and in schizophrenia [28]. MMP9 stimulates the receptor for advanced glycation end-products (RAGE), eventually leading to the secretion of various cytokines; changes in the extracellular matrix can finally impinge on the balance between excitation and inhibition, and on synaptic plasticity $[29,30]$. Another novel mechanism reinforcing neuroinflammation is supported by the renin-angiotensin system (RAS), which reinforces immune system activation; blocking this pathway prevents neurobehavioral effects of neuroinflammation, induced by lipopolysaccharide (LPS) treatment [31].

Considering this background, the goal of our review is to show some of the known aspects of the mechanistic relationship between neuroinflammation and epilepsy, mainly focusing on certain paradigmatic diseases as focal cortical dysplasia, PCDH19 epilepsy, glioblastoma multiforme (GBM), maternal immune activation, multiple sclerosis, autism spectrum disorders (ASD) associated with epilepsy, and SARS-COV-2 (Figure 1). Following this, we finally explore several therapies that are currently being employed in epileptic patients, targeting neuroinflammation. 


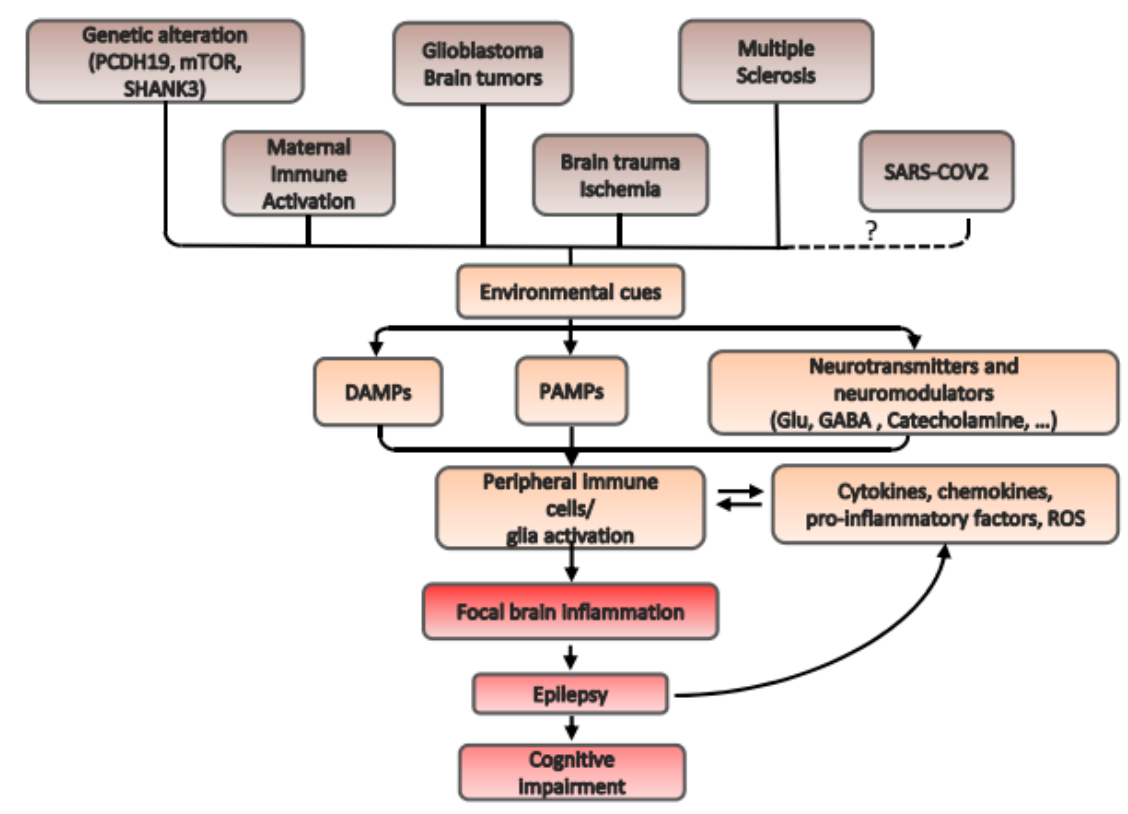

Figure 1. Schematic diagram of the interaction between epilepsy and neuroinflammation. Epilepsy is related to neuroinflammation and neuroinflammation can induce epilepsy in a biunivocal interaction. Many molecular mechanisms have been described to be involved in this loop. Diverse mechanisms, here summarized in the diagram, can impinge by means of the interaction with environmental cues on damage-associated molecular patterns (DAMPs), pathogen-associated molecular patterns (PAMPs) or on neurotransmitters and neuromodulators. Dotted lines and question mark indicate the possible involvement of SARS-COV2 in this loop; studies about its mechanism of action are currently ongoing.

\section{Mechanisms of Neuroinflammation in Some Exemplificative Pathologies Related to Different Forms of Epilepsy}

\subsection{Structural Epilepsy: Focal Cortical Dysplasia}

Focal cortical dysplasia (FCD) is due to an anomaly in cortical development, and it is among the first causes of drug-resistant epilepsy in children and in adults [32]. Several typologies of FCD have been classified according to their peculiar anatomical and functional alterations [33]. These alterations, characterized by the emergence of balloon cells or disrupted lamination, or by the presence of ectopic neurons, are often caused by genetic mosaic mutations of genes involved in the mTOR pathway $[33,34]$.

Such neuronal abnormalities are accompanied by neuroinflammation, and the degree of activated microglia correlates with seizure duration and frequency [35]. However, it is still unclear to what extent neuroinflammation contributes to the development of epileptic seizures, even though it is clearly not a mere epiphenomenon [36].

In 2016, in resected brains from FCD patients, it was shown that microglial activation could be partially caused by CD47/SIRP- $\alpha$ - and CD200/CD200R-mediated reductions in the immune inhibitory pathways, where chronic neuroinflammation has been observed [37].

Recently, in eight children affected by FCD type II, the inflammatory molecule signaling of high-mobility group box 1 (HMGB1) through Toll-like receptor 4 (HMGB1-TLR4), was found to be altered. Pro-inflammatory cytokines downstream to HMGB1 were upregulated in tissues coming from the resected area compared to those from the perilesional zone [38], even if this did not correlate with the severity of epilepsy.

On the contrary, some studies demonstrated a positive correlation between two biomarkers of neuroinflammation, respectively, human leukocyte antigen-DR isotype (HLA-DR) and IL-17, and the frequency of seizures per month (Figure 2; [35,39]). 


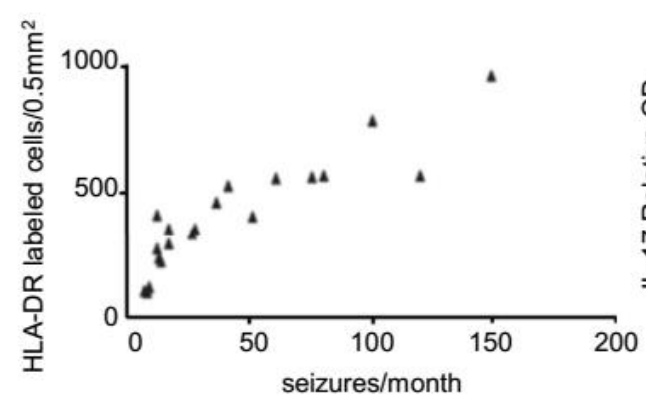

(a)

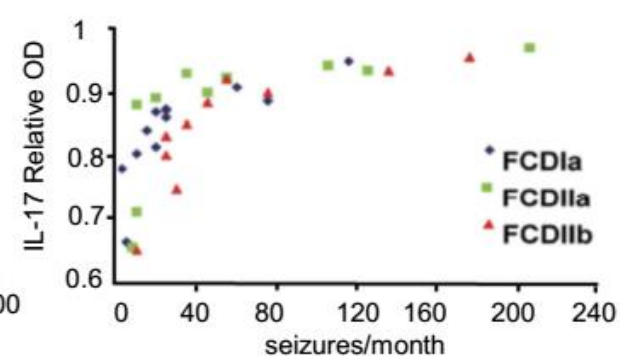

(b)

Figure 2. Correlation between inflammatory pathways and frequency of seizures in two exemplificative studies done in FCD patients. (a) Positive correlation between the distribution of cells of the activated microglia/macrophage lineage (HLA-DR positive cells) and frequency of seizures (replotted with permission from [35]). (b) Positive correlation between IL-17 positive cells and frequency of seizures in three different types of FCD (IL-17 relative optical density is expressed in y-axis; replotted with permission from [39]).

However, it is not known if there is a correlation between remission from epilepsy and reduction in neuroinflammation, and such a study would be particularly important to predict remission in childhood epilepsy [40].

However, mechanistic studies are limited by the lack of animal models for FCD reproducing all the features of the human disease, and by the poor access to human samples. In the last few years, new animal models based on genetic manipulations that better simulate the human pathology have been produced [41]. Some of these models rely on the use of in utero electroporation to alter the proteins of the mTOR pathway [42-44]. Therefore, it is likely that in the future, more insights can be gained on the functional connection between upregulated inflammatory molecules and epileptic seizure genesis/progression, in order to find better biomarkers for the prognosis of this disease.

\subsection{Genetic Epilepsy: PCDH19 Epilepsy}

A possible involvement of neuroinflammation has been proposed for PCDH19 epilepsy. This syndrome is characterized by seizures starting in early infancy, as well as behavioral problems, intellectual disability, and developmental delay [45,46]. It is caused by mutations in the X chromosomal gene Pcdh19 and, interestingly, affects heterozygous females, while hemizygous males are spared [45]. The seizures show sensitivity to fever and tend to occur in clusters. The sensitivity to fever has led researchers to hypothesize that the immune system might be involved in seizure generation [47]. Therefore, Higurashi et al. set out to investigate the efficacy of corticosteroid application to treat seizures in five PCDH19 epilepsy patients. In all five patients, seizures ceased rapidly, even if the effects were transient. Two case reports followed Higurashi's work, confirming the rapid cessation of seizure clusters in PCDH19 patients upon corticosteroid administration [48,49]. Interestingly, Higurashi et al. reported one patient to whom corticosteroids were successfully administered prophylactically. Also, the patient from Lee and Chung's study showed no recurrence of seizures for at least three years after corticosteroid treatment [49]. These results warrant research into the prophylactic use of corticosteroids in PCDH19 epilepsy.

The pathogenesis of PCDH19 epilepsy is still unclear. To explain the efficacy of corticosteroids in treating the disease, Higurashi et al. speculated about BBB disruptions as a possible pathogenic mechanism. BBB disruptions are known to interfere with brain homeostasis and trigger seizures. Corticosteroids can improve BBB integrity and thereby protect against seizures [50]. Indeed, such a mechanism of action could explain why PCDH19 epilepsy patients respond so rapidly to corticosteroid treatment. Further support for this hypothesis comes from the detection of antibodies against several epitopes of the NMDA receptor in the cerebrospinal fluid (CSF) of patients after seizures. Such antibodies indicate a non-specific immune response against neuronal proteins that were degraded 
during the seizure. Their presence in the CSF suggests that they leaked from the brain into the CSF, through a weakened BBB. Finally, PCDH19 is highly expressed in endothelial cells of the brain [51], and it is possible that in heterozygous females PCDH19 mosaic expression interferes with BBB integrity. Future research in mouse models of PCDH19 epilepsy should elucidate whether BBB disruptions are a feature of the syndrome and what molecular pathways are involved in this pathogenesis.

\subsection{Brain Tumors: Glioblastoma Multiforme}

Glioblastoma multiforme (GBM) is the most common and lethal primary brain tumor, with an average life expectancy of 12-15 months. The standard treatment procedures, combining surgery, radiation, and chemotherapy, are not capable of contrasting it [52]. Due to its robust vascularization and invasive properties, its five-year survival rate is only about 3.3\% [53]. GBM has been classified into four different subtypes, recognized as neural, pro-neural, mesenchymal and classical GBMs [54,55]. Inflammation spreads in all subtypes of GBM, but it is more profound in the mesenchymal subtype, which, interestingly, has the worst prognosis [56].

GBM is associated with hyper-excitability and seizures at different rates $[57,58]$. Together with other brain tumors, GBM is the second most common cause of focal intractable epilepsy $[59,60]$.

The following three types of mechanisms have been involved in explaining high GBM invasiveness and proliferation: (1) alteration of the microglia [61], (2) changes in the GBM microenvironment throughout the activation of cytokines cascades, and (3) BBB disruption and angiogenesis [62].

Firstly, microglia play an important role in immune surveillance and represent the largest tumor-infiltrating cell population, contributing up to $30 \%$ of the total tumor mass. The gene expression pattern of microglia interacting with GBM cells is altered. GBM can circumvent the neuroimmune system by lowering its tumor-sensing abilities, suppressing immune responses, and promoting tumor invasion processes [63]. It has been seen that upon hyperactivation, mTOR signaling promotes cell proliferation and metabolism, and thereby contributes to this tumor initiation and progression [64].

Next, the tumor microenvironment sustains tumor progression by releasing inflammatory cues in response to its dynamic interaction with endogenous cells [65-68]. Waters et al. identified two cytokines, IL- $1 \beta$ and oncostatin M (OSM), that activate Re1B/p50 complexes through the NF- $\mathrm{KB}$ pathway, causing an increase in pro-inflammatory cytokines in GBM cells and a worse prognosis in patients [69]. Likewise, a study observed a significant rise in GBM cell proliferation promoted by IL-1 $\beta$-induced ERK activation [70], while another one reported increased levels of IL-1 $\beta$ receptors in human GBM cell lines (U87MG) overexpressing epidermal growth factor receptor variant III (EGFRvIII) [71]. It is known that downstream of IL-1 $\beta$, IL-6 and IL-8 promote tumor growth and invasion [72-74]; specifically, IL-6 seems to be a poor prognostic factor for patients' survival [75]. Indeed, IL-6 sustains angiogenesis, acting on endothelial cells and astrocytes through the activation of vascular endothelial growth factor (VEGF) and fibroblast growth factor (FGF) [71]. Another role for IL-6 released by microglia was recently shown in vitro, where IL-6 contributes not only to angiogenesis, but also to increased interstitial fluid pressure, edema formation, and changes in blood flow, ultimately causing defective drug delivery [76].

Indeed, pro-inflammatory cytokines are thought to trigger BBB disruption [77] and this is one of the main causes of brain tumor-related edema (BTRE). BTRE is one of the main causes of the mortality of GBM, since the accumulation of fluids within the rigid skull rapidly increases the intracranial pressure, which can result in decreased cerebral flow, ischemia, brain herniation, and death [78]. Both in animal models and human patients affected by GBM, a beneficial effect of treatment with corticosteroids (e.g., dexamethasone) has been shown. Indeed, this treatment reduces peritumoral fluid, even though the exact mechanism for its action is poorly understood. The following two explanations have been suggested: a direct action of dexamethasone on the vessel components, or a more 
general anti-inflammatory action that might counter the effect of inflammatory cytokines in BBB breakdown [79].

So, neuroinflammation represents the principal cause of high GBM proliferation and could also impinge, at the same time, on the altered brain excitability. Further studies need to be done in this direction.

\subsection{Epilepsy Caused by Infection: Maternal Immune Activation}

Converging lines of evidence from basic science and clinical studies suggest a relationship between perturbations of the maternal immune system during pregnancy and neurodevelopmental disorders such ASD and schizophrenia [80]. Indeed, maternal immune activation (MIA) can trigger seizures in the offspring [81]. MIA can be induced in animal models by the administration of either LPS or polyinosinic:polycytidylic acid (PIC) to pregnant females. It is worth noting that MIA can cause astrogliosis [82]. In a recent paper [83], in a model of LPS-induced MIA, the administration of the pro-epileptic drug pentylenetetrazol (PTZ) to the offspring caused seizures in these mice, once adult, which were more severe and frequent, and an enhancement of anxiety-like behavior compared to the control mice. Then, these MIA mice were more vulnerable to the cognitive impairment caused by treatment with PTZ. Finally, since the inflammatory cytokines TNF- $\alpha$ and IL-10 are involved in MIA, the authors measured the presence of these proteins in the hippocampus of the offspring, and they found that MIA significantly enhanced TNF- $\alpha$ and IL-10 production there.

Previously, in a different model of MIA (obtained by injection of PIC), Washington and colleagues [84] found that after prenatal exposure to IL-6, seizures induced by kainic acid (KA) administration were less frequent. Instead, co-exposure to IL- 6 and IL-1 $\beta$ in the same time window increased seizure frequency. Also, other studies have shown a synergic role of IL-6 and IL-1 $\beta$ in regulating hyper-excitability [85].

Another molecular explanation on the mechanisms involved in MIA-induced epilepsy was recently provided by Corradini [86]. Indeed, a single PIC injection at embryonal stage nine was sufficient to increase offspring susceptibility to seizures at three months of age (P90). In contrast, PIC administration in adult mice did not increase the susceptibility to seizures. Even if neuroinflammatory markers, as the number of microglial (Iba+) cells and the activation of CD11b and GFAP, were found to be normal, the authors found an alteration in network activity. In this model, prenatal exposure to pro-inflammatory molecules produced a delay in the normal excitatory-to-inhibitory switch of the neurotransmitter GABA. Indeed, during physiological cortical development, the effect of GABA release changes from excitatory to inhibitory [87]. In this model, prenatal exposure to neuroinflammation changed ionic transporter NKCC1 and KCC2 expression, and consequently intracellular chloride concentration; treatment with the NKCC1 antagonist bumetanide rescued the phenotype. GABA was shown to retain an excitatory effect in acute slices of adult mice in this MIA-induced epilepsy model. This suggests a delay in the excitatory/inhibitory switch of chloride, as already shown for numerous other pathological models, including spinal cord lesions, chronic pain, brain trauma, cerebrovascular infarcts, autism, Rett and Down syndrome, various types of epilepsies, and other genetic or environmental insults [88].

\subsection{Autoimmune Neurodegenerative Disease: Multiple Sclerosis}

Multiple sclerosis (MS) is a neurodegenerative disease of the CNS, characterized by the demyelination of neural axons, mediated by the immune system [89]. MS is the most frequent cause of non-traumatic neurological disability in young adults. Its onset is generally between 20 and 40 years; MS signs and symptoms can vary in severity, and include motor impairment, tremor, vertigo, weakness, pain and vision loss [90].

Although its cause is still unknown, this autoimmune disease has a multifactorial origin, and it seems to be associated with several genetic and environmental factors. Some factors are variants of genes involved in the immune response, such as HLA, IL2RA and IL7RA, which are also related to an increased risk of developing other autoimmune diseases [91]. 
MS is manifested with typical lesions of the nervous tissue, called focal plaques, characterized by the de-myelinization of axons. The extension and inflammatory activity in these lesions can vary depending on the form of MS. Usually active lesions present a high level of neuroinflammation, and there is a local disruption of BBB and a high density of immune cells as lymphocytes, activated microglia and macrophages. Indeed, analogously to GBM, also in MS, the protective effect of BBB is disrupted, and this allows pro-inflammatory factors and immune cells circulating in the blood stream to reach the CNS and contribute to inflammation [92]. Moreover, a physiological alteration of astrocytes with pronounced astrogliosis has been found in models of MS, with perturbed expression of astrocytic molecules controlling brain homeostasis and excitability, as water channels (AQP4) and synaptic glutamate transporters (EAAT2) [93].

Notably, an increase in the prevalence of epileptic seizures has been observed in MS patients $[94,95]$. The increase is about three to six times compared to the general population and the link between the two pathologies is not well understood [96,97].

In particular, in a Swedish population, a meta-analysis study showed a correlation between the severity of MS (including increased duration, increased disability, and progressive, as opposed to relapsing remitting disease) and the appearance of epilepsy [98]. Moreover, lesions in the brain and spinal cord of MS patients can cause involuntary movements that look like seizures. These seizure mimics are called non-epileptic seizure-like activity, and can be recognized by a lack of signature in EEG, and they should be treated differently from seizures [99]. Published studies on the presence of epileptic seizures in MS have been focused mostly on the epidemiology and treatment $[94,96,100,101]$. Importantly, some treatments, such as interferons, baclofen, and aminopyridines acting to limit MS symptoms, can elicit epilepsy and should be applied in a case-by-case modality.

Thus, considering the role of neuroinflammation in both MS and epilepsy, it can be worthwhile to further investigate the role of pro-inflammatory factors in seizures affecting MS patients. This could be a starting point for the development of new treatments or better management of already known therapeutics.

\subsection{A New Infection Associated to Altered Brain Excitability with Unknown Etiology: SARS-CoV-2}

Emerging evidence suggests that the coronavirus SARS-CoV-2, the etiologic agent of coronavirus disease 2019 (COVID-19), can cause neurological complications, even though its main target is the respiratory system [102]. An increasing amount of research suggests an association of SARS-Cov-2 to hypoxic/ischemic encephalopathy, acute cerebrovascular disease, and impaired consciousness in hospitalized Chinese patients in Wuhan $[103,104]$. Moreover, neurological widespread symptoms, including encephalopathy, prominent agitation and confusion, and corticospinal tract signs, have been found in a cohort of French patients [105]. Finally, epilepsy has been correlated with SARS-CoV-2- induced neuroinflammation [106-109].

SARS-CoV-2 is a coronavirus (severe acute respiratory syndrome-coronavirus-2) that emerged in late 2019 in China, and it is characterized by severe respiratory problems that are often associated with gastrointestinal infections. Often starting like a normal flu, it can fastly degenerate attacking lungs. Until now, it is the third among the CoVs to have been originated in these last 20 years (together with CoVs causing SARS in 2002/2003 and MERS in 2012), but it is surely the most aggressive. Indeed, SARS-CoV-2 is responsible for an ongoing pandemic.

Although studies testing whether SARS-CoV-2 targets the brain in humans or animal models are not yet available, it is well established that other CoVs, such as CoVOC43, [110-114] target the CNS and cause neurological alterations, including brain inflammation and encephalomyelitis. If SARS-CoV-2 was indeed to target the brain, there could be important long-term consequences on the CNS. Research has demonstrated that chemokine presence in the brain, caused by prolonged inflammation, can contribute to chronic illness, neurodegeneration, psychiatric disease, and epilepsy $[115,116]$. 
Anosmia and taste loss, associated with COVID-19, also raise some of the following interesting questions: are they caused by a peripheral effect of SARS-CoV-2 (e.g., on the olfactory nerve, taste receptors), or are they related to a direct effect on the CNS? Additionally, evidence was found that SARS-CoV-2 could enter the CNS by crossing the neural-mucosal interface in the olfactory mucosa [117]. Therefore, the mechanisms of action and entry of SARS-CoV-2 in the brain should be extensively investigated, to better understand its correlation with its temporary or long-lasting neurological effects. It is known that SARS-Cov-2 binds to cells via the S1 subunit of its spike protein. Rhea and coworkers [118] have now demonstrated that intravenously injected radio-iodinated S1 (I-S1) readily crossed the BBB in male mice, entering the parenchymal brain space. I-S1 was also taken up by the lung, spleen, kidney and liver. Intranasal administration of I-S1 also entered the brain, although at levels roughly ten times lower than intravenous administration.

The investigation on how COVID-19 affects the brain is still ongoing, but neurological alterations appear to be common in COVID-19 patients; a meta-analysis reported that 96.1\% of COVID-19 patients present an abnormal EEG [119]. The percentage of COVID19 patients that developed de novo seizures was reported to be low by some studies $(0.47-0.66 \%$ [104,120]; some cases have been reported of patients showing high levels of inflammation and epileptiform brain activity [121]. Notably, some patients with epilepsy experienced an increase in seizure frequency [122]. This could be caused by other environmental factors, such as the enhanced level of emotional distress and anxiety that these patients had to face during the COVID-19 pandemic. Indeed, many patients with epilepsy perceived a lack of care towards their condition [122]. Interestingly, some patients with epilepsy have reported a decrease in the frequency of their seizures, and this could be caused by the isolation and reduction in events that trigger seizures [123].

Apart from the indirect effects of the CODIV-19 pandemic on patients with epilepsy, a direct effect of COVID-19 on the increase in seizures and on de novo seizures cannot be excluded. The possible mechanism is still to be uncovered, but some possible factors have been found. In COVID-19 patients, an increase in the production of pro-inflammatory cytokines (TNF- $\alpha$, IL-6, IL-1B) had been reported [124], which is linked to neurotoxicity and epilepsy. COVID-19 infection also causes a break-down of the BBB [124]. As already stated, such a disruption can cause osmotic imbalance in the brain, and allows immune cells and peripheral pro-inflammatory cytokines to enter the central nervous system. Indeed, the $\mathrm{BBB}$ disruption, as we have already seen in previous paragraphs, appears to be common in neural pathologies that show co-morbidity with epilepsy, such as PCDH19 epilepsy, glioblastoma and multiple sclerosis.

Neurologists should be aware that autoimmune neurologic complications involving the CNS might occur, and neurological complications should be promptly recognized and treated to reduce permanent neurologic disability, as in the case of acute disseminated encephalopathy [125] or of Guillain-Barré syndrome, which is an acute dysimmune neuropathy [126].

Finally, although most people that were affected showed no or mild symptoms upon SARS-CoV-2 infection, the severity increases in elderly people [127]. In aged subjects, neuroinflammation can be potentiated by the activation of pre-existing or new inflammatory cascades activated by COVID-19, as well as by a stressful lifestyle caused by the pandemic, creating a vicious circle that leads to a global increase in mortality [127].

\subsection{Alterations in Gut Microbiota in Epilepsy and in Autism Spectrum Disorders with Co-Morbidity with Epilepsy}

In these last years, a relationship between the brain and the gut microbiota has been proposed, which can ultimately be involved in brain inflammation through the still poorly understood relationship between immune responses and the CNS. Postnatal brain development is paralleled by the maturation of the ecosystem of symbionts populating the gastrointestinal (GI) tract. Interestingly, it has been seen that possessing a healthy microbiome might play a key role in correct neurodevelopment during the early stages of 
life [128]. On the contrary, in many neurological diseases, such as in ASD and epilepsy, an alteration in gut microbiota has been shown [129-134].

Moreover, several alterations in gut microbiota associated with intestinal problems have been found in other neuropsychiatric disorders of potential neurodevelopmental origins, such as schizophrenia [128,135-137], bipolar disorder [138] and depression [139,140], where the balance between excitation and inhibition is impaired [141].

Recently, it has been shown that in Shank3 knock-out (KO) mice, a model of Phelan McDermid syndrome (PMS), a form of autism associated with drug-resistant epilepsy, there is a significantly different GI morphology associated with alterations in the microbiota composition in feces, which may contribute to inflammatory responses [142]. This happens because Shank and other synaptic proteins are also expressed in enterocytes [143]. Moreover, a change in inflammatory cytokine levels was reported [144], and higher E. coli LPS expression in liver samples of PMS, together with an increase in IL-6 and activated astrocytes [142]. Dysbiosis of the microbiota in ASD is consistent with a disruption of the intestinal permeability, with consequent influences on the interaction between the gut and brain [145]. A paper by Möhle and co-workers [146] has shown that the immune response is a gateway between commensal bacteria in the GI trait and the CNS. Indeed, after antibiotic treatment, reduced neurogenesis is produced by the decreased infiltration of specific immune cells, i.e., Ly6Chi monocytes. Conversely, if the Ly6Chi population is treated with probiotics and exercise, or if Ly6Chi monocytes are adoptively transferred in animals treated with antibiotics, there is a rescue of hippocampal neurogenesis. Then, in a model of kindling, where stress facilitates epileptogenesis, it has been demonstrated that this effect is mediated by the microbiome [147]. Another study shows a change in the microbiome in patients with focal idiopathic epilepsy with respect to healthy subjects [148]. Finally, it has been shown that a ketogenic diet can be helpful in treating epilepsy, because it can have an impact on microbiome regulation [149].

\section{An Overview on Therapies Affecting Neuroinflammation with Possible Outcome in Epilepsy}

Finally, on the basis of the interaction between epilepsy and neuroinflammation that we have illustrated in general, and for some exemplificative pathologies, in this section we summarize several therapeutic strategies directed to contrast neuroinflammation and impinging on amelioration of the epileptic phenotype (Figure 3). Many of these drugs have been selected on the basis of results from preclinical studies in different animal models of epilepsy [150], and thanks to the discovery of several biomarkers in patients [151]. This section, far from being exhaustive on this issue, tries to recapitulate principal results in the treatment of epilepsy, also evidencing some problems related to the use of drugs that stop neuroinflammation.

\subsection{Inhibition of Immune Response}

First of all, neuroinflammation involves complex interactions between innate and adaptive immunity, as seen in animal models [153]. The main goal of immunotherapy is to reduce acute inflammation and minimize irreversible neuronal dysfunction. People with autoimmune epilepsy may usually have clinical problems in addition to their seizures, including psychiatric difficulties, cognitive problems, balance impairment, sleep disorder, and autonomic (involuntary actions such as breathing or heartbeat) dysfunction, which should be treated apart. Interfering with these molecular cascades has been seen as beneficial in treating epilepsy with several of the following different drugs:

- Corticosteroids and especially adrenocorticotropic hormone (ACTH) have been used in various forms of childhood epilepsy, as in the case of PCDH19 female epilepsy ([47]; see the previous paragraph);

- Antagonists of Toll-like receptor have been efficaciously used in convulsive epilepsy, as in the case of resveratrol, an anti-inflammatory stilbenoid. The application of resveratrol reduced the frequency of spontaneous seizures in KA-treated rats [154]. This effect was 
associated with a reduction in neuronal cell loss and an inhibition of mossy fiber sprouting in the hippocampus;

- Inhibition of the prostaglandin E2-PGE2- receptor subtype is neuroprotective in a pilocarpine model of SE [155];

- Immunosuppressants, such as cyclosporine A, FK-506 (also known as tacrolimus), and rapamycin inhibiting T-lymphocyte activation, can stop seizures [156]. Indeed, daily systemic injection of cyclosporine A or FK-506 during electrical amygdala kindling prevented the acquisition of severe chronic seizures in rats [157]. However, long-term protection from crisis failed after drug withdrawal, showing limited anticonvulsant capacities [158]. Moreover, these data are quite controversial, since other authors showed opposite effects [159]; - Immunoglobulins (IVIg) have been first employed in intractable epilepsy, starting from the empirical observation of its beneficial effect on seizures [160]. Indeed, immune system dysfunction could trigger, maintain or, unexpectedly, sustain intractable seizures [161]; - In status epilepticus, minocycline represents a promising candidate for the anti-inflammatory treatment of epilepsy [162,163]. Despite often being referred to as an inhibitor of microglial activation, minocycline also affects-either directly or indirectly-other cell types, such as neurons, astrocytes, and oligodendrocytes. A similar drug, Minozac, blocks the production of pro-inflammatory cytokines and prevents the cognitive degenerative phenotype associated in a mouse 'two-hit' model of epilepsy [164]. Interestingly, an IL-1 $\beta$ inhibitor, VX-765, being used in psoriasis therapy, completed phase 2 clinical trials in 60 people with treatment-resistant partial-onset epilepsy [165].

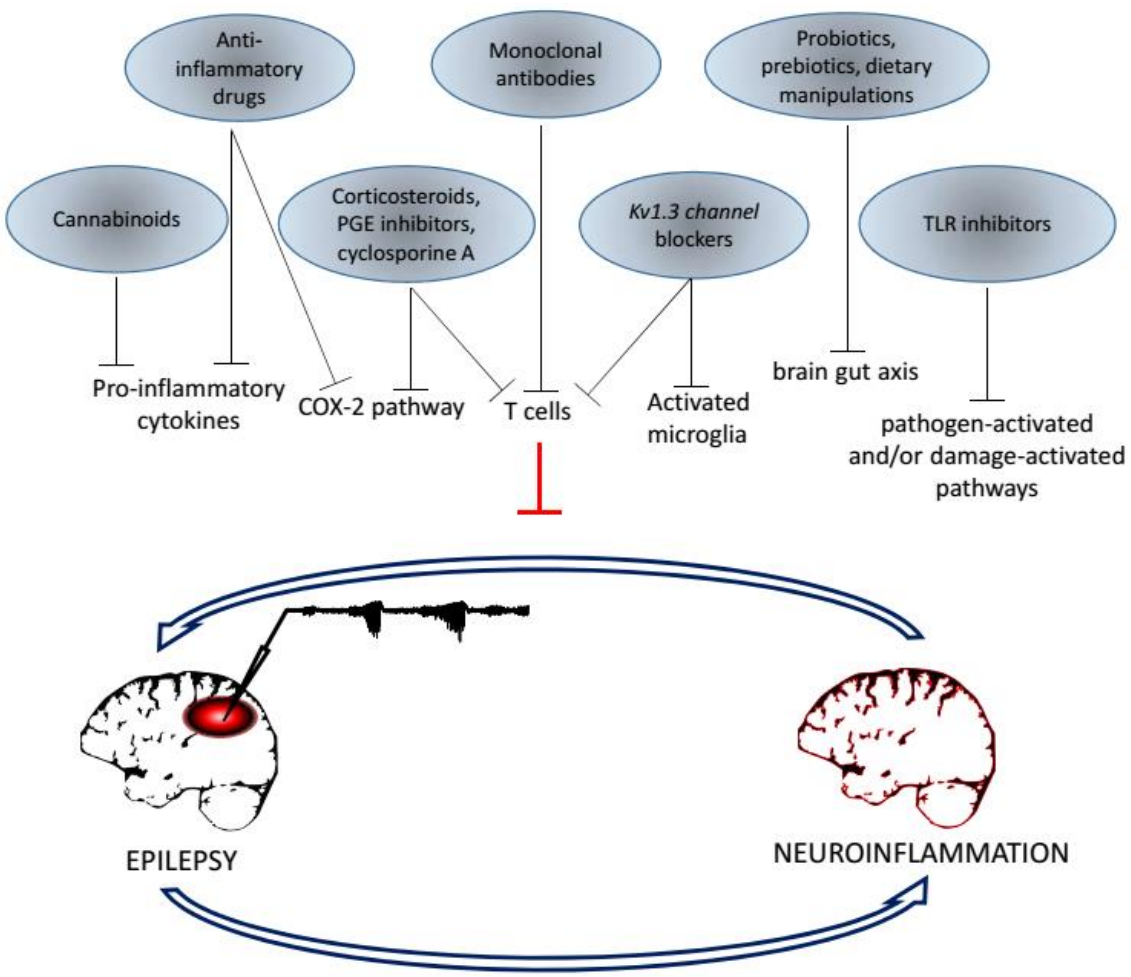

Figure 3. Schematic representation of attempted therapeutic strategies targeting neuroinflammation and capable to ameliorate epilepsy. The diagram illustrates the interaction with specific families of drugs and their targets; their main function seems to interrupt the loop that reinforces neuroinflammation produced by epileptogenesis. The trace recorded from the left brain is a typical example of critical activity due to the localized treatment with the convulsive agent 4-AP in our experiments, as conducted in [152].

\subsection{Antibody Antagonists}

Monoclonal antibodies against immune cell membrane proteins, such as efalizumab and natalizumab, already used in autoimmune pathologies such as psoriasis, multiple 
sclerosis and Crohn's disease [166], have been used to target serum auto-antibodies in epileptogenesis [167]. Some ameliorations have been found after early treatment with immunomodulatory therapies, in autoimmune encephalitis and autoimmune epilepsies. Recently, autoantibodies against the IL-1 blockade are proposed for refractory epilepsy in an adolescent female with pharmaco-resistant epilepsy with a good outcome [168]. Then, tocilizumab, a humanized monoclonal antibody against the IL-6 receptor, has been found to be successful in a case report of two patients with pediatric refractory status epilepticus and acute epilepsy [169]. It is clear that there is the lack of standardized researches in this field, despite evidences emerging from basic research. The reason is that it is often difficult to find the right target of patients to be treated, due to the fact that the critical step is to intervene as early as possible [161].

\subsection{Probiotics}

According to the results in animal models, the use of probiotics, prebiotics (as probiotic nutrients) and dietary manipulations, such as a ketogenic diet, could be promising to regulate homeostasis in brain excitability [170]. However, standardized studies with controlled administration of probiotics need to be done to better investigate this issue [171,172]. For example, a recent clinical trial reported a beneficial effect of probiotics in a pilot study, with a reduction in seizures to a $50 \%$ level in about $30 \%$ of the subjects, and a general amelioration of life quality [173].

\subsection{Cannabinoids}

The endocannabinoid system (ECS) has been shown to contribute to neuroinflammation, and neuroinflammation can cause epilepsy; consequently, there is much evidence about the positive use of cannabinoids to treat chronic epilepsy [7]. Indeed, ECS can modulate the balance between excitation and inhibition, through the release of endogenous cannabinoids (endocannabinoids). Specifically, during neuroinflammation cannabidiols inhibit the activity of cyclooxygenase-2 (CO-X 2), 5-lipoxygenase and cytochrome $\mathrm{P} 450$, reducing the expression of inflammatory molecules, such as prostaglandins and leukotrienes [174]. Interestingly, a drug belonging to this class, Epidiolex, has been very recently approved by the FDA as a treatment for pharmaco-resistant epilepsy in Dravet syndrome [175]. Moreover, the use of phytocannabinoids, i.e., active molecules present in Cannabis sativa, has been effective in a wide range of pathologies with neurological correlates, among which are chronic pain, nausea, and multiple sclerosis. However, more studies are needed in this field, since cannabidiols and its derivatives are still considered illegal in several countries, and because a secondary collateral effect of phytocannabinoids cannot be neglected in many cases [174].

\subsection{Inhibitors of Voltage-Gated Potassium Channels Kv1.3}

Another therapeutical strategy to block neuroinflammation is the use of inhibitors of voltage-gated potassium channels Kv1.3 [176]. Importantly, abnormal expression of Kv1.3 channels has been demonstrated to also be correlated with epilepsy [176]. Toxins produced by sea anemones, scorpions, spiders, snakes, and cone snails can target specific subsets of T lymphocytes as well as microglial cells, acting on their Kv1.3 channels and blocking neuroinflammation. Clinical trials to explore the efficacy of this treatment are currently ongoing, even if a problem could be the difficulty for these venoms to pass BBB.

\section{Conclusions}

Patients with drug-resistant epilepsy and many animal models of epilepsy show active inflammation [177]. So far, pediatric patients with refractory seizures that are resistant to common anti-epileptic drugs have been mostly treated with drugs counteracting neuroinflammation $[178,179]$. What appears evident is that drugs acting on various inflammatory pathways can mitigate the epileptic phenotype, but the response is both subject-based and dependent on the type of pathology causing epilepsy, as we have seen from this 
overview. Blocking neuroinflammation can be especially effective in counteracting the cascade mechanisms of recurrent seizures. As a future perspective, it would be important to explore if a pretreatment with anti-inflammatory drugs could block the emergence of seizures in subjects that are prone to epilepsy because of genetic diseases, brain trauma, tumors, infections, or SARS-COV2.

Further studies in this field are necessary in order to understand if neuroinflammation is a signature or a cause of epilepsy, or both, in order to better orient the time-course of therapies and to standardize protocols involving anti-inflammatory treatments.

Funding: This review study was supported by funding from] Fondazione Pisa, Project RST 148/16.

Institutional Review Board Statement: Not applicable.

Informed Consent Statement: Not applicable.

Data Availability Statement: We followed MDPI Research Data Policies.

Acknowledgments: We thank Gian Michele Ratto, Laura Baroncelli, Elena Putignano and Gabriele Nardi for the critical reading of this manuscript.

Conflicts of Interest: The authors declare no conflict of interest.

\section{References}

1. DiSabato, D.J.; Quan, N.; Godbout, J.P. Neuroinflammation: The devil is in the details. J. Neurochem. 2016, 139, 136-153. [CrossRef] [PubMed]

2. Gilhus, N.E.; Deuschl, G. Neuroinflammation-A common thread in neurological disorders. Nat. Rev. Neurol. 2019, 15, 429-430. [CrossRef]

3. Cervellati, C.; Trentini, A.; Pecorelli, A.; Valacchi, G. Inflammation in Neurological Disorders: The Thin Boundary between Brain and Periphery. Antioxid. Redox Signal. 2020, 33, 191-210. [CrossRef] [PubMed]

4. Vaillant, J.A.A.; Qurie, A. Interleukin; StatPearls Publishing: Treasure Island, FL, USA, 2021.

5. Rodríguez-Gómez, J.A.; Kavanagh, E.; Engskog-Vlachos, P.; Engskog, M.K.R.; Herrera, A.J.; Espinosa-Oliva, A.M.; Joseph, B.; Hajji, N.; Venero, J.L.; Burguillos, M.A. Microglia: Agents of the CNS Pro-Inflammatory Response. Cells 2020, 9, 1717. [CrossRef]

6. Yang, Q.; Wang, G.; Zhang, F. Role of Peripheral Immune Cells-Mediated Inflammation on the Process of Neurodegenerative Diseases. Front. Immunol. 2020, 11. [CrossRef]

7. Vezzani, A.; Balosso, S.; Ravizza, T. Neuroinflammatory pathways as treatment targets and biomarkers in epilepsy. Nat. Rev. Neurol. 2019, 15, 459-472. [CrossRef] [PubMed]

8. Rana, A.; Musto, A.E. The role of inflammation in the development of epilepsy. J. Neuroinflamm. 2018, 15. [CrossRef] [PubMed]

9. Scheffer, I.E.; Berkovic, S.; Capovilla, G.; Connolly, M.B.; French, J.; Guilhoto, L.; Hirsch, E.; Jain, S.; Mathern, G.W.; Moshé, S.L.; et al. ILAE classification of the epilepsies: Position paper of the ILAE Commission for Classification and Terminology. Epilepsia 2017, 58, 512-521. [CrossRef] [PubMed]

10. Ong, M.S.; Kohane, I.S.; Cai, T.; Gorman, M.P.; Mandl, K.D. Population-level evidence for an autoimmune etiology of epilepsy. JAMA Neurol. 2014, 71, 569-574. [CrossRef]

11. Geis, C.; Planagumà, J.; Carreño, M.; Graus, F.; Dalmau, J. Autoimmune seizures and epilepsy. J. Clin. Investig. 2019, 129, 926-940. [CrossRef]

12. Barker-Haliski, M.L.; Löscher, W.; White, H.S.; Galanopoulou, A.S. Neuroinflammation in epileptogenesis: Insights and translational perspectives from new models of epilepsy. Epilepsia 2017, 58, 39-47. [CrossRef]

13. Meng, F.; Yao, L. The role of inflammation in epileptogenesis. Acta Epileptol. 2020, 2, 15. [CrossRef]

14. Löscher, W.; Potschka, H.; Sisodiya, S.M.; Vezzani, A. Drug resistance in epilepsy: Clinical impact, potential mechanisms, and new innovative treatment options. Pharmacol. Rev. 2020, 72, 606-638. [CrossRef]

15. Goddard, G.V. Development of epileptic seizures through brain stimulation at low intensity. Nature 1967, $214,1020-1021$. [CrossRef]

16. Pitkänen, A.; Löscher, W.; Vezzani, A.; Becker, A.J.; Simonato, M.; Lukasiuk, K.; Gröhn, O.; Bankstahl, J.P.; Friedman, A.; Aronica, E.; et al. Advances in the development of biomarkers for epilepsy. Lancet Neurol. 2016, 15, 843-856. [CrossRef]

17. Ravizza, T.; Vezzani, A. Pharmacological targeting of brain inflammation in epilepsy: Therapeutic perspectives from experimental and clinical studies. Epilepsia Open 2018, 3, 133-142. [CrossRef]

18. Kim, I.; Mlsna, L.M.; Yoon, S.; Le, B.; Yu, S.; Xu, D.; Koh, S. A postnatal peak in microglial development in the mouse hippocampus is correlated with heightened sensitivity to seizure triggers. Brain Behav. 2015, 5, 1-4. [CrossRef] [PubMed]

19. Hanke, M.L.; Kielian, T. Toll-like receptors in health and disease in the brain: Mechanisms and therapeutic potential. Clin. Sci. 2011, 121, 367-387. [CrossRef] [PubMed]

20. Xiang, W.; Chao, Z.-Y.; Feng, D.-Y. Role of Toll-like receptor/MYD88 signaling in neurodegenerative diseases. Rev. Neurosci. 2015, 26, 407-414. [CrossRef] [PubMed] 
21. Dinarello, C.A. Overview of the IL-1 family in innate inflammation and acquired immunity. Immunol. Rev. 2018, $281,8-27$. [CrossRef]

22. Bianchi, M.E.; Manfredi, A.A. Dangers in and out. Science 2009, 323, 1683-1684. [CrossRef]

23. Maroso, M.; Balosso, S.; Ravizza, T.; Liu, J.; Aronica, E.; Iyer, A.M.; Rossetti, C.; Molteni, M.; Casalgrandi, M.; Manfredi, A.A.; et al. Toll-like receptor 4 and high-mobility group box-1 are involved in ictogenesis and can be targeted to reduce seizures. Nat. Med. 2010, 16, 413-419. [CrossRef] [PubMed]

24. Lin, Z.; Gu, Y.; Zhou, R.; Wang, M.; Guo, Y.; Chen, Y.; Ma, J.; Xiao, F.; Wang, X.; Tian, X. Serum Exosomal Proteins F9 and TSP-1 as Potential Diagnostic Biomarkers for Newly Diagnosed Epilepsy. Front. Neurosci. 2020, 14. [CrossRef] [PubMed]

25. Pepys, M.B. The Pentraxins 1975-2018: Serendipity, Diagnostics and Drugs. Front. Immunol. 2018, 9, 2382. [CrossRef]

26. Ummenthum, K.; Peferoen, L.A.N.; Finardi, A.; Baker, D.; Pryce, G.; Mantovani, A.; Bsibsi, M.; Bottazzi, B.; Peferoen-Baert, R.; van der Valk, P.; et al. Pentraxin-3 is upregulated in the central nervous system during MS and EAE, but does not modulate experimental neurological disease. Eur. J. Immunol. 2016, 46, 701-711. [CrossRef] [PubMed]

27. Bronisz, E.; Kurkowska-Jastrzębska, I. Matrix Metalloproteinase 9 in Epilepsy: The Role of Neuroinflammation in Seizure Development. Mediators Inflamm. 2016, 2016. [CrossRef]

28. Dwir, D.; Giangreco, B.; Xin, L.; Tenenbaum, L.; Cabungcal, J.H.; Steullet, P.; Goupil, A.; Cleusix, M.; Jenni, R.; Chtarto, A.; et al. MMP9/RAGE pathway overactivation mediates redox dysregulation and neuroinflammation, leading to inhibitory/excitatory imbalance: A reverse translation study in schizophrenia patients. Mol. Psychiatry 2020, 25, 2889-2904. [CrossRef]

29. De Vivo, L.; Landi, S.; Panniello, M.; Baroncelli, L.; Chierzi, S.; Mariotti, L.; Spolidoro, M.; Pizzorusso, T.; Maffei, L.; Ratto, G.M. Extracellular matrix inhibits structural and functional plasticity of dendritic spines in the adult visual cortex. Nat. Commun. 2013, 4, 1484. [CrossRef]

30. Faini, G.; Aguirre, A.; Landi, S.; Lamers, D.; Pizzorusso, T.; Ratto, G.M.; Deleuze, C.; Bacci, A. Perineuronal nets control visual input via thalamic recruitment of cortical PV interneurons. Elife 2018, 7, e41520. [CrossRef]

31. Gong, X.; Hu, H.; Qiao, Y.; Xu, P.; Yang, M.; Dang, R.; Han, W.; Guo, Y.; Chen, D.; Jiang, P. The Involvement of Renin-Angiotensin System in Lipopolysaccharide-Induced Behavioral Changes, Neuroinflammation, and Disturbed Insulin Signaling. Front. Pharmacol. 2019, 10, 318. [CrossRef]

32. Guerrini, R.; Duchowny, M.; Jayakar, P.; Krsek, P.; Kahane, P.; Tassi, L.; Melani, F.; Polster, T.; Andre, V.M.; Cepeda, C.; et al. Diagnostic methods and treatment options for focal cortical dysplasia. Epilepsia 2015, 56, 1669-1686. [CrossRef]

33. Guerrini, R.; Dobyns, W.B. Malformations of cortical development: Clinical features and genetic causes. Lancet Neurol. 2014, 13, 710-726. [CrossRef]

34. D'Gama, A.M.; Walsh, C.A. Somatic mosaicism and neurodevelopmental disease. Nat. Neurosci. 2018, 21, 1504-1514. [CrossRef] [PubMed]

35. Boer, K.; Spliet, W.G.M.; Van Rijen, P.C.; Redeker, S.; Troost, D.; Aronica, E. Evidence of activated microglia in focal cortical dysplasia. J. Neuroimmunol. 2006, 173, 188-195. [CrossRef] [PubMed]

36. Crino, P.B. Focal cortical dysplasia. Semin. Neurol. 2015, 35, 201-208. [CrossRef]

37. Sun, F.J.; Zhang, C.Q.; Chen, X.; Wei, Y.J.; Li, S.; Liu, S.Y.; Zang, Z.-1.; He, J.J.; Guo, W.; Yang, H. Downregulation of CD47 and CD200 in patients with focal cortical dysplasia type Ilb and tuberous sclerosis complex. J. Neuroinflamm. 2016, 13. [CrossRef]

38. Zhang, Z.; Liu, Q.; Liu, M.; Wang, H.; Dong, Y.; Ji, T.; Liu, X.; Jiang, Y.; Cai, L.; Wu, Y. Upregulation of HMGB1-TLR4 inflammatory pathway in focal cortical dysplasia type II. J. Neuroinflamm. 2018, 15. [CrossRef]

39. He, J.J.; Li, S.; Shu, H.F.; Yu, S.X.; Liu, S.Y.; Yin, Q.; Yang, H. The interleukin 17 system in cortical lesions in focal cortical dysplasias. J. Neuropathol. Exp. Neurol. 2013, 72, 152-163. [CrossRef]

40. Berg, A.T.; Rychlik, K.; Levy, S.R.; Testa, F.M. Complete remission of childhood-onset epilepsy: Stability and prediction over two decades. Brain 2014, 137, 3213-3222. [CrossRef]

41. Wong, M. Animal models of focal cortical dysplasia and tuberous sclerosis complex: Recent progress toward clinical applications. Epilepsia 2009, 50, 34-44. [CrossRef]

42. Hsieh, L.S.; Wen, J.H.; Claycomb, K.; Huang, Y.; Harrsch, F.A.; Naegele, J.R.; Hyder, F.; Buchanan, G.F.; Bordey, A. Convulsive seizures from experimental focal cortical dysplasia occur independently of cell misplacement. Nat. Commun. 2016, 7. [CrossRef] [PubMed]

43. Ribierre, T.; Deleuze, C.; Bacq, A.; Baldassari, S.; Marsan, E.; Chipaux, M.; Muraca, G.; Roussel, D.; Navarro, V.; Leguern, E.; et al. Second-hit mosaic mutation in mTORC1 repressor DEPDC5 causes focal cortical dysplasia-associated epilepsy. J. Clin. Investig. 2018, 128, 2452-2458. [CrossRef] [PubMed]

44. Trovato, F.; Parra, R.; Pracucci, E.; Landi, S.; Cozzolino, O.; Nardi, G.; Cruciani, F.; Pillai, V.; Mosti, L.; Cwetsch, A.W.; et al. Modelling genetic mosaicism of neurodevelopmental disorders in vivo by a Cre-amplifying fluorescent reporter. Nat. Commun. 2020, 11. [CrossRef] [PubMed]

45. Dibbens, L.M.; Tarpey, P.S.; Hynes, K.; Bayly, M.A.; Scheffer, I.E.; Smith, R.; Bomar, J.; Sutton, E.; Vandeleur, L.; Shoubridge, C.; et al. X-linked protocadherin 19 mutations cause female-limited epilepsy and cognitive impairment. Nat. Genet. 2008, 40, 776-781. [CrossRef]

46. Depienne, C.; Bouteiller, D.; Keren, B.; Cheuret, E.; Poirier, K.; Trouillard, O.; Benyahia, B.; Quelin, C.; Carpentier, W.; Julia, S.; et al. Correction: Sporadic Infantile Epileptic Encephalopathy Caused by Mutations in PCDH19 Resembles Dravet Syndrome but Mainly Affects Females. PLoS Genet. 2009, 5. [CrossRef] 
47. Higurashi, N.; Takahashi, Y.; Kashimada, A.; Sugawara, Y.; Sakuma, H.; Tomonoh, Y.; Inoue, T.; Hoshina, M.; Satomi, R.; Ohfu, M.; et al. Immediate suppression of seizure clusters by corticosteroids in PCDH19 female epilepsy. Seizure 2015, 27, 1-5. [CrossRef]

48. Bertani, G.; Spagnoli, C.; Iodice, A.; Salerno, G.G.; Frattini, D.; Fusco, C. Steroids efficacy in the acute management of seizure clusters in one case of PCDH19 female epilepsy. Seizure 2015, 32, 45-46. [CrossRef] [PubMed]

49. Lee, D.M.; Chung, H.J. A Case of Effective Treatment of a Patient with PCDH 19- Related Epilepsy using Corticosteroid. J. Korean Child Neurol. Soc. 2018, 26, 32-37. [CrossRef]

50. Marchi, N.; Granata, T.; Freri, E.; Ciusani, E.; Ragona, F.; Puvenna, V.; Teng, Q.; Alexopolous, A.; Janigro, D. Efficacy of antiinflammatory therapy in a model of acute seizures and in a population of pediatric drug resistant epileptics. PLoS ONE 2011, 6, e18200. [CrossRef]

51. Cooper, S.R.; Jontes, J.D.; Sotomayor, M. Structural determinants of adhesion by protocadherin-19 and implications for its role in epilepsy. Elife 2016, 5. [CrossRef]

52. Taylor, O.G.; Brzozowski, J.S.; Skelding, K.A. Glioblastoma Multiforme: An Overview of Emerging Therapeutic Targets. Front. Oncol. 2019, 9, 963. [CrossRef] [PubMed]

53. Ostrom, Q.T.; Cioffi, G.; Gittleman, H.; Patil, N.; Waite, K.; Kruchko, C.; Barnholtz-Sloan, J.S. CBTRUS Statistical Report: Primary Brain and Other Central Nervous System Tumors Diagnosed in the United States in 2012-2016. Neuro. Oncol. 2019, 21, V1-V100. [CrossRef]

54. Verhaak, R.G.W.; Hoadley, K.A.; Purdom, E.; Wang, V.; Qi, Y.; Wilkerson, M.D.; Miller, C.R.; Ding, L.; Golub, T.; Mesirov, J.P.; et al. Integrated Genomic Analysis Identifies Clinically Relevant Subtypes of Glioblastoma Characterized by Abnormalities in PDGFRA, IDH1, EGFR, and NF1. Cancer Cell 2010, 17, 98-110. [CrossRef]

55. Phillips, H.S.; Kharbanda, S.; Chen, R.; Forrest, W.F.; Soriano, R.H.; Wu, T.D.; Misra, A.; Nigro, J.M.; Colman, H.; Soroceanu, L.; et al. Molecular subclasses of high-grade glioma predict prognosis, delineate a pattern of disease progression, and resemble stages in neurogenesis. Cancer Cell 2006, 9, 157-173. [CrossRef]

56. Arimappamagan, A.; Somasundaram, K.; Thennarasu, K.; Peddagangannagari, S.; Srinivasan, H.; Shailaja, B.C.; Samuel, C.; Patric, I.R.P.; Shukla, S.; Thota, B.; et al. A Fourteen Gene GBM Prognostic Signature Identifies Association of Immune Response Pathway and Mesenchymal Subtype with High Risk Group. PLoS ONE 2013, 8, e62042. [CrossRef] [PubMed]

57. Liang, J.; Lv, X.; Lu, C.; Ye, X.; Chen, X.; Fu, J.; Luo, C.; Zhao, Y. Prognostic factors of patients with Gliomas-An analysis on 335 patients with Glioblastoma and other forms of Gliomas. BMC Cancer 2020, 20, 35. [CrossRef] [PubMed]

58. Venkatesh, H.S.; Morishita, W.; Geraghty, A.C.; Silverbush, D.; Gillespie, S.M.; Arzt, M.; Tam, L.T.; Espenel, C.; Ponnuswami, A.; $\mathrm{Ni}$, L.; et al. Electrical and synaptic integration of glioma into neural circuits. Nature 2019, 573, 539-545. [CrossRef] [PubMed]

59. Ertürk Çetin, Ö.; İşler, C.; Uzan, M.; Özkara, Ç. Epilepsy-related brain tumors. Seizure 2017, 44, 93-97. [CrossRef] [PubMed]

60. Berendsen, S.; Spliet, W.G.M.; Geurts, M.; Van Hecke, W.; Seute, T.; Snijders, T.J.; Bours, V.; Bell, E.H.; Chakravarti, A.; Robe, P.A. Epilepsy Associates with Decreased HIF-1 $\alpha /$ STAT5b Signaling in Glioblastoma. Cancers 2019, 11, 41. [CrossRef]

61. Tremblay, P.; Beaudet, M.J.; Tremblay, E.; Rueda, N.; Thomas, T.; Vallières, L. Matrix metalloproteinase 2 attenuates brain tumour growth, while promoting macrophage recruitment and vascular repair. J. Pathol. 2011, 224, 222-233. [CrossRef]

62. Van Tellingen, O.; Yetkin-Arik, B.; De Gooijer, M.C.; Wesseling, P.; Wurdinger, T.; De Vries, H.E. Overcoming the blood-brain tumor barrier for effective glioblastoma treatment. Drug Resist. Updat. 2015, 19, 1-12. [CrossRef] [PubMed]

63. Brown, N.F.; Carter, T.J.; Ottaviani, D.; Mulholland, P. Harnessing the immune system in glioblastoma. Br. J. Cancer 2018, 119, 1171-1181. [CrossRef] [PubMed]

64. Tian, T.; Li, X.; Zhang, J. mTOR Signaling in Cancer and mTOR Inhibitors in Solid Tumor Targeting Therapy. Int. J. Mol. Sci. 2019, 20, 755. [CrossRef] [PubMed]

65. Di Virgilio, F.; Sarti, A.C.; Falzoni, S.; De Marchi, E.; Adinolfi, E. Extracellular ATP and P2 purinergic signalling in the tumour microenvironment. Nat. Rev. Cancer 2018, 18, 601-618. [CrossRef] [PubMed]

66. Charles, N.A.; Holland, E.C.; Gilbertson, R.; Glass, R.; Kettenmann, H. The brain tumor microenvironment. Glia 2012, 60, 502-514. [CrossRef] [PubMed]

67. Curran, C.S.; Bertics, P.J. Eosinophils in glioblastoma biology. J. Neuroinflamm. 2012, 9. [CrossRef]

68. Sowers, J.L.; Johnson, K.M.; Conrad, C.; Patterson, J.T.; Sowers, L.C. The role of inflammation in brain cancer. Adv. Exp. Med. Biol. 2014, 816, 75-105. [CrossRef] [PubMed]

69. Waters, M.R.; Gupta, A.S.; Mockenhaupt, K.; Brown, L.S.N.; Biswas, D.D.; Kordula, T. RelB acts as a molecular switch driving chronic inflammation in glioblastoma multiforme. Oncogenesis 2019, 8. [CrossRef] [PubMed]

70. Meini, A.; Sticozzi, C.; Massai, L.; Palmi, M. A nitric oxide/Ca 2+/calmodulin/ERK1/2 mitogen-activated protein kinase pathway is involved in the mitogenic effect of IL-1 $\beta$ in human astrocytoma cells. Br. J. Pharmacol. 2008, 153, 1706-1717. [CrossRef]

71. Yeung, Y.T.; McDonald, K.L.; Grewal, T.; Munoz, L. Interleukins in glioblastoma pathophysiology: Implications for therapy. Br. J. Pharmacol. 2013, 168, 591-606. [CrossRef]

72. Tanabe, K.; Kozawa, O.; Iida, H. Midazolam suppresses interleukin-1 $\beta$-induced interleukin- 6 release from rat glial cells. J. Neuroinflamm. 2011, 8, 68. [CrossRef]

73. Hirano, T.; Ishihara, K.; Hibi, M. Roles of STAT3 in mediating the cell growth, differentiation and survival signals relayed through the IL-6 family of cytokine receptors. Oncogene 2000, 19, 2548-2556. [CrossRef] 
74. Hodge, D.R.; Hurt, E.M.; Farrar, W.L. The role of IL-6 and STAT3 in inflammation and cancer. Eur. J. Cancer 2005, 41, 2502-2512. [CrossRef] [PubMed]

75. Hori, T.; Sasayama, T.; Tanaka, K.; Koma, Y.-I.; Nishihara, M.; Tanaka, H.; Nakamizo, S.; Nagashima, H.; Maeyama, M.; Fujita, Y.; et al. Tumor-associated macrophage related interleukin-6 in cerebrospinal fluid as a prognostic marker for glioblastoma. J. Clin. Neurosci. 2019, 68, 281-289. [CrossRef] [PubMed]

76. Couto, M.; Coelho-Santos, V.; Santos, L.; Fontes-Ribeiro, C.; Silva, A.P.; Gomes, C.M.F. The interplay between glioblastoma and microglia cells leads to endothelial cell monolayer dysfunction via the interleukin-6-induced JAK2/STAT3 pathway. J. Cell. Physiol. 2019, 234, 19750-19760. [CrossRef] [PubMed]

77. Ryan, R.; Booth, S.; Price, S. Corticosteroid-use in primary and secondary brain tumour patients: A review. J. Neurooncol. 2012, 106, 449-459. [CrossRef]

78. Papadopoulos, M.C.; Saadoun, S.; Binder, D.K.; Manley, G.T.; Krishna, S.; Verkman, A.S. Molecular mechanisms of brain tumor edema. Neuroscience 2004, 129, 1009-1018. [CrossRef]

79. Dubois, L.G.; Campanati, L.; Righy, C.; D’Andrea-Meira, I.; de Sampaio e Spohr, T.C.L.; Porto-Carreiro, I.; Pereira, C.M.; Balça-Silva, J.; Kahn, S.A.; DosSantos, M.F.; et al. Gliomas and the vascular fragility of the blood brain barrier. Front. Cell. Neurosci. 2014, 8. [CrossRef]

80. Solek, C.M.; Farooqi, N.; Verly, M.; Lim, T.K.; Ruthazer, E.S. Maternal immune activation in neurodevelopmental disorders. Dev. Dyn. 2018, 247, 588-619. [CrossRef]

81. Glass, H.C.; Pham, T.N.; Danielsen, B.; Towner, D.; Glidden, D.; Wu, Y.W. Antenatal and Intrapartum Risk Factors for Seizures in Term Newborns: A Population-Based Study, California 1998-2002. J. Pediatr. 2009, 154. [CrossRef]

82. Samuelsson, A.M.; Jennische, E.; Hansson, H.A.; Holmäng, A. Prenatal exposure to interleukin-6 results in inflammatory neurodegeneration in hippocampus with NMDA/GABAA dysregulation and impaired spatial learning. Am. J. Physiol. Regul. Integr. Comp. Physiol. 2006, 290, 1345-1356. [CrossRef]

83. Zeraati, M.; Najdi, N.; Mosaferi, B.; Salari, A.A. Environmental enrichment alters neurobehavioral development following maternal immune activation in mice offspring with epilepsy. Behav. Brain Res. 2021, 399. [CrossRef]

84. Washington, J.; Kumar, U.; Medel-Matus, J.S.; Shin, D.; Sankar, R.; Mazarati, A. Cytokine-dependent bidirectional connection between impaired social behavior and susceptibility to seizures associated with maternal immune activation in mice. Epilepsy Behav. 2015, 50, 40-45. [CrossRef]

85. Pineda, E.; Shin, D.; You, S.J.; Auvin, S.; Sankar, R.; Mazarati, A. Maternal immune activation promotes hippocampal kindling epileptogenesis in mice. Ann. Neurol. 2013, 74, 11-19. [CrossRef]

86. Corradini, I.; Focchi, E.; Rasile, M.; Morini, R.; Desiato, G.; Tomasoni, R.; Lizier, M.; Ghirardini, E.; Fesce, R.; Morone, D.; et al. Maternal Immune Activation Delays Excitatory-to-Inhibitory Gamma-Aminobutyric Acid Switch in Offspring. Biol. Psychiatry 2018, 83, 680-691. [CrossRef] [PubMed]

87. Ben-Ari, Y. Excitatory actions of gaba during development: The nature of the nurture. Nat. Rev. Neurosci. 2002, 3, 728-739. [CrossRef] [PubMed]

88. Ben-Ari, Y. NKCC1 Chloride Importer Antagonists Attenuate Many Neurological and Psychiatric Disorders. Trends Neurosci. 2017, 40, 536-554. [CrossRef] [PubMed]

89. Filippi, M.; Bar-Or, A.; Piehl, F.; Preziosa, P.; Solari, A.; Vukusic, S.; Rocca, M.A. Multiple sclerosis. Nat. Rev. Dis. Prim. 2018, 4, 43. [CrossRef] [PubMed]

90. Compston, A.; Coles, A. Multiple sclerosis. Lancet 2008, 372, 1502-1517. [CrossRef]

91. Baranzini, S.E.; Oksenberg, J.R. The Genetics of Multiple Sclerosis: From 0 to 200 in 50 Years. Trends Genet. 2017, 33, 960-970. [CrossRef]

92. Ortiz, G.G.; Pacheco-Moisés, F.P.; Macías-Islas, M.Á.; Flores-Alvarado, L.J.; Mireles-Ramírez, M.A.; González-Renovato, E.D.; Hernández-Navarro, V.E.; Sánchez-López, A.L.; Alatorre-Jiménez, M.A. Role of the blood-brain barrier in multiple sclerosis. Arch. Med. Res. 2014, 45, 687-697. [CrossRef]

93. Lapato, A.S.; Thompson, S.M.; Parra, K.; Tiwari-Woodruff, S.K. Astrocyte Glutamate Uptake and Water Homeostasis Are Dysregulated in the Hippocampus of Multiple Sclerosis Patients with Seizures. ASN Neuro 2020, 12, 1759091420979604. [CrossRef]

94. Dagiasi, I.; Vall, V.; Kumlien, E.; Burman, J.; Zelano, J. Treatment of epilepsy in multiple sclerosis. Seizure 2018, 58, 47-51. [CrossRef]

95. Chou, I.J.; Kuo, C.F.; Tanasescu, R.; Tench, C.R.; Tiley, C.G.; Constantinescu, C.S.; Whitehouse, W.P. Epilepsy and associated mortality in patients with multiple sclerosis. Eur. J. Neurol. 2019, 26, 342-e23. [CrossRef]

96. Langenbruch, L.; Krämer, J.; Güler, S.; Möddel, G.; Geßner, S.; Melzer, N.; Elger, C.E.; Wiendl, H.; Budde, T.; Meuth, S.G.; et al. Seizures and epilepsy in multiple sclerosis: Epidemiology and prognosis in a large tertiary referral center. J. Neurol. 2019, 266, 1789-1795. [CrossRef] [PubMed]

97. Poser, C.M.; Brinar, V. V Epilepsy and multiple sclerosis. Epilepsy Behav. 2003, 4, 6-12. [CrossRef]

98. Pack, A. Is There a Relationship Between Multiple Sclerosis and Epilepsy? If So What Does It Tell Us About Epileptogenesis? Epilepsy Curr. 2018, 18, 95-96. [CrossRef]

99. Neuß, F.; von Podewils, F.; Wang, Z.I.; Süße, M.; Zettl, U.K.; Grothe, M. Epileptic seizures in multiple sclerosis: Prevalence, competing causes and diagnostic accuracy. J. Neurol. 2021, 268, 1721-1727. [CrossRef] 
100. DePaula-Silva, A.B.; Hanak, T.J.; Libbey, J.E.; Fujinami, R.S. Theiler's murine encephalomyelitis virus infection of SJL/J and C57BL/6J mice: Models for multiple sclerosis and epilepsy. J. Neuroimmunol. 2017, 308, 30-42. [CrossRef]

101. Mahamud, Z.; Burman, J.; Zelano, J. Prognostic impact of epilepsy in multiple sclerosis. Mult. Scler. Relat. Disord. 2020, $38,101497$. [CrossRef]

102. Steardo, L.; Steardo, L.; Zorec, R.; Verkhratsky, A. Neuroinfection may contribute to pathophysiology and clinical manifestations of COVID-19. Acta Physiol. 2020, 229. [CrossRef]

103. Chen, T.; Wu, D.; Chen, H.; Yan, W.; Yang, D.; Chen, G.; Ma, K.; Xu, D.; Yu, H.; Wang, H.; et al. Clinical characteristics of 113 deceased patients with coronavirus disease 2019: Retrospective study. BMJ 2020, 368. [CrossRef]

104. Mao, L.; Jin, H.; Wang, M.; Hu, Y.; Chen, S.; He, Q.; Chang, J.; Hong, C.; Zhou, Y.; Wang, D.; et al. Neurologic Manifestations of Hospitalized Patients with Coronavirus Disease 2019 in Wuhan, China. JAMA Neurol. 2020, 77, 683-690. [CrossRef]

105. Helms, J.; Kremer, S.; Merdji, H.; Clere-Jehl, R.; Schenck, M.; Kummerlen, C.; Collange, O.; Boulay, C.; Fafi-Kremer, S.; Ohana, M.; et al. Neurologic Features in Severe SARS-CoV-2 Infection. N. Engl. J. Med. 2020, 382, 2268-2270. [CrossRef]

106. Jiang, F.; Deng, L.; Zhang, L.; Cai, Y.; Cheung, C.W.; Xia, Z. Review of the Clinical Characteristics of Coronavirus Disease 2019 (COVID-19). J. Gen. Intern. Med. 2020, 35, 1545-1549. [CrossRef]

107. Azhideh, A. COVID-19 Neurological Manifestations. Int. Clin. Neurosci. J. 2020, 7, 54. [CrossRef]

108. Niazkar, H.R.; Zibaee, B.; Nasimi, A.; Bahri, N. The neurological manifestations of COVID-19: A review article. Neurol. Sci. 2020, 41, 1667-1671. [CrossRef]

109. Najjar, S.; Najjar, A.; Chong, D.J.; Pramanik, B.K.; Kirsch, C.; Kuzniecky, R.I.; Pacia, S.V.; Azhar, S. Central nervous system complications associated with SARS-CoV-2 infection: Integrative concepts of pathophysiology and case reports. J. Neuroinflamm. 2020, 17, 17. [CrossRef]

110. Murray, R.S.; Brown, B.; Brain, D.; Cabirac, G.F. Detection of coronavirus RNA and antigen in multiple sclerosis brain. Ann. Neurol. 1992, 31, 525-533. [CrossRef]

111. Hung, E.C.W.; Chim, S.S.C.; Chan, P.K.S.; Tong, Y.K.; Ng, E.K.O.; Chiu, R.W.K.; Leung, C.B.; Sung, J.J.Y.; Tam, J.S.; Lo, Y.M.D. Detection of SARS Coronavirus RNA in the Cerebrospinal Fluid of a Patient with Severe Acute Respiratory Syndrome. Clin. Chem. 2003, 49, 2108-2109. [CrossRef]

112. Morfopoulou, S.; Brown, J.R.; Davies, E.G.; Anderson, G.; Virasami, A.; Qasim, W.; Chong, W.K.; Hubank, M.; Plagnol, V.; Desforges, M.; et al. Human Coronavirus OC43 Associated with Fatal Encephalitis. N. Engl. J. Med. 2016, 375, 497-498. [CrossRef]

113. Desforges, M.; Le Coupanec, A.; Dubeau, P.; Bourgouin, A.; Lajoie, L.; Dubé, M.; Talbot, P.J. Human coronaviruses and other respiratory viruses: Underestimated opportunistic pathogens of the central nervous system? Viruses 2019, 12, 14. [CrossRef] [PubMed]

114. Nilsson, A.; Edner, N.; Albert, J.; Ternhag, A. Fatal encephalitis associated with coronavirus OC43 in an immunocompromised child. Infect. Dis. 2020, 52, 419-422. [CrossRef]

115. Skinner, D.; Marro, B.S.; Lane, T.E. Chemokine CXCL10 and Coronavirus-Induced Neurologic Disease. Viral Immunol. 2019, 32, 25-37. [CrossRef] [PubMed]

116. Serrano-Castro, P.J.; Estivill-Torrús, G.; Cabezudo-García, P.; Reyes-Bueno, J.A.; Ciano Petersen, N.; Aguilar-Castillo, M.J.; Suárez-Pérez, J.; Jiménez-Hernández, M.D.; Moya-Molina, M.; Oliver-Martos, B.; et al. Impact of SARS-CoV-2 infection on neurodegenerative and neuropsychiatric diseases: A delayed pandemic? Neurologia 2020, 35, 245-251. [CrossRef] [PubMed]

117. Meinhardt, J.; Radke, J.; Dittmayer, C.; Franz, J.; Thomas, C.; Mothes, R.; Laue, M.; Schneider, J.; Brünink, S.; Greuel, S.; et al. Olfactory transmucosal SARS-CoV-2 invasion as a port of central nervous system entry in individuals with COVID-19. Nat. Neurosci. 2021, 24, 168-175. [CrossRef] [PubMed]

118. Rhea, E.M.; Logsdon, A.F.; Hansen, K.M.; Williams, L.M.; Reed, M.J.; Baumann, K.K.; Holden, S.J.; Raber, J.; Banks, W.A.; Erickson, M.A. The S1 protein of SARS-CoV-2 crosses the blood-brain barrier in mice. Nat. Neurosci. 2020. [CrossRef]

119. Kubota, T.; Gajera, P.K.; Kuroda, N. Meta-analysis of EEG findings in patients with COVID-19. Epilepsy Behav. 2021, 115, 107682. [CrossRef]

120. Lu, L.; Xiong, W.; Liu, D.; Liu, J.; Yang, D.; Li, N.; Mu, J.; Guo, J.; Li, W.; Wang, G.; et al. New onset acute symptomatic seizure and risk factors in coronavirus disease 2019: A retrospective multicenter study. Epilepsia 2020, 61, e49-e53. [CrossRef]

121. Hwang, S.T.; Ballout, A.A.; Mirza, U.; Sonti, A.N.; Husain, A.; Kirsch, C.; Kuzniecky, R.; Najjar, S. Acute Seizures Occurring in Association With SARS-CoV-2. Front. Neurol. 2020, 11, 576329. [CrossRef]

122. Asadi-Pooya, A.A.; Simani, L.; Shahisavandi, M.; Barzegar, Z. COVID-19, de novo seizures, and epilepsy: A systematic review. Neurol. Sci. 2021, 42, 415-431. [CrossRef]

123. D'Orsi, G.; Mazzeo, F.; Ravidà, D.; Di Claudio, M.T.; Sabetta, A.; Lalla, A.; Sbrizzi, S.; Avolio, C. The effect of quarantine due to Covid-19 pandemic on seizure frequency in 102 adult people with epilepsy from Apulia and Basilicata regions, Southern Italy. Clin. Neurol. Neurosurg. 2021, 203, 106592. [CrossRef] [PubMed]

124. Nikbakht, F.; Mohammadkhanizadeh, A.; Mohammadi, E. How does the COVID-19 cause seizure and epilepsy in patients? The potential mechanisms. Mult. Scler. Relat. Disord. 2020, 46, 102535. [CrossRef]

125. Novi, G.; Rossi, T.; Pedemonte, E.; Saitta, L.; Rolla, C.; Roccatagliata, L.; Inglese, M.; Farinini, D. Acute disseminated encephalomyelitis after SARS-CoV-2 infection. Neurol. Neuroimmunol. Neuroinflamm. 2020, 7. [CrossRef] 
126. Alberti, P.; Beretta, S.; Piatti, M.; Karantzoulis, A.; Piatti, M.L.; Santoro, P.; Viganò, M.; Giovannelli, G.; Pirro, F.; Montisano, D.A.; et al. Guillain-Barré syndrome related to COVID-19 infection. Neurol. Neuroimmunol. NeuroInflamm. 2020, 7. [CrossRef]

127. Bossù, P.; Toppi, E.; Sterbini, V.; Spalletta, G. Implication of aging related chronic neuroinflammation on covid-19 pandemic. J. Pers. Med. 2020, 10, 102. [CrossRef]

128. Borre, Y.E.; O'Keeffe, G.W.; Clarke, G.; Stanton, C.; Dinan, T.G.; Cryan, J.F. Microbiota and neurodevelopmental windows: Implications for brain disorders. Trends Mol. Med. 2014, 20, 509-518. [CrossRef]

129. Fan, Y.; Wang, H.; Liu, X.; Zhang, J.; Liu, G. Crosstalk between the Ketogenic Diet and Epilepsy: From the Perspective of Gut Microbiota. Mediat. Inflamm. 2019, 2019, 8373060. [CrossRef]

130. De Caro, C.; Iannone, L.F.; Citraro, R.; Striano, P.; De Sarro, G.; Constanti, A.; Cryan, J.F.; Russo, E. Can we "seize" the gut microbiota to treat epilepsy? Neurosci. Biobehav. Rev. 2019, 107, 750-764. [CrossRef]

131. Olson, C.A.; Vuong, H.E.; Yano, J.M.; Liang, Q.Y.; Nusbaum, D.J.; Hsiao, E.Y. The Gut Microbiota Mediates the Anti-Seizure Effects of the Ketogenic Diet. Cell 2018, 173, 1728-1741.e13. [CrossRef]

132. Lum, G.R.; Olson, C.A.; Hsiao, E.Y. Emerging roles for the intestinal microbiome in epilepsy. Neurobiol. Dis. 2020, $135,104576$. [CrossRef]

133. Vendrik, K.E.W.; Ooijevaar, R.E.; de Jong, P.R.C.; Laman, J.D.; van Oosten, B.W.; van Hilten, J.J.; Ducarmon, Q.R.; Keller, J.J.; Kuijper, E.J.; Contarino, M.F. Fecal Microbiota Transplantation in Neurological Disorders. Front. Cell. Infect. Microbiol. 2020, 10, 98 [CrossRef] [PubMed]

134. Srikantha, P.; Mohajeri, M.H. The Possible Role of the Microbiota-Gut-Brain-Axis in Autism Spectrum Disorder. Int. J. Mol. Sci. 2019, 20, 2115. [CrossRef] [PubMed]

135. Sherwin, E.; Sandhu, K.V.; Dinan, T.G.; Cryan, J.F. May the Force Be With You: The Light and Dark Sides of the Microbiota-GutBrain Axis in Neuropsychiatry. CNS Drugs 2016, 30, 1019-1041. [CrossRef]

136. Groer, M.W.; Luciano, A.A.; Dishaw, L.J.; Ashmeade, T.L.; Miller, E.; Gilbert, J.A. Development of the preterm infant gut microbiome: A research priority. Microbiome 2014, 2. [CrossRef] [PubMed]

137. Gibson, M.K.; Wang, B.; Ahmadi, S.; Burnham, C.A.D.; Tarr, P.I.; Warner, B.B.; Dantas, G. Developmental dynamics of the preterm infant gut microbiota and antibiotic resistome. Nat. Microbiol. 2016, 1, 16024. [CrossRef]

138. Dickerson, F.; Severance, E.; Yolken, R. The microbiome, immunity, and schizophrenia and bipolar disorder. Brain. Behav. Immun. 2017, 62, 46-52. [CrossRef] [PubMed]

139. Hagan, C.C.; Graham, J.M.E.; Wilkinson, P.O.; Midgley, N.; Suckling, J.; Sahakian, B.J.; Goodyer, I.M. Neurodevelopment and ages of onset in depressive disorders. Lancet Psychiatry 2015, 2, 1112-1116. [CrossRef]

140. Mangiola, F.; Ianiro, G.; Franceschi, F.; Fagiuoli, S.; Gasbarrini, G.; Gasbarrini, A. Gut microbiota in autism and mood disorders. World J. Gastroenterol. 2016, 22, 361-368. [CrossRef]

141. Tatti, R.; Haley, M.S.; Swanson, O.K.; Tselha, T.; Maffei, A. Neurophysiology and Regulation of the Balance between Excitation and Inhibition in Neocortical Circuits. Biol. Psychiatry 2017, 81, 821-831. [CrossRef]

142. Sauer, A.K.; Bockmann, J.; Steinestel, K.; Boeckers, T.M.; Grabrucker, A.M. Altered intestinal morphology and microbiota composition in the autism spectrum disorders associated SHANK3 mouse model. Int. J. Mol. Sci. 2019, 20, 2134. [CrossRef] [PubMed]

143. Pfaender, S.; Sauer, A.K.; Hagmeyer, S.; Mangus, K.; Linta, L.; Liebau, S.; Bockmann, J.; Huguet, G.; Bourgeron, T.; Boeckers, T.M.; et al. Zinc deficiency and low enterocyte zinc transporter expression in human patients with autism related mutations in SHANK3. Sci. Rep. 2017, 7. [CrossRef]

144. Tabouy, L.; Getselter, D.; Ziv, O.; Karpuj, M.; Tabouy, T.; Lukic, I.; Maayouf, R.; Werbner, N.; Ben-Amram, H.; Nuriel-Ohayon, M.; et al. Dysbiosis of microbiome and probiotic treatment in a genetic model of autism spectrum disorders. Brain. Behav. Immun. 2018, 73, 310-319. [CrossRef]

145. De Magistris, L.; Familiari, V.; Pascotto, A.; Sapone, A.; Frolli, A.; Iardino, P.; Carteni, M.; De Rosa, M.; Francavilla, R.; Riegler, G.; et al. Alterations of the intestinal barrier in patients with autism spectrum disorders and in their first-degree relatives. J. Pediatr. Gastroenterol. Nutr. 2010, 51, 418-424. [CrossRef]

146. Möhle, L.; Mattei, D.; Heimesaat, M.M.; Bereswill, S.; Fischer, A.; Alutis, M.; French, T.; Hambardzumyan, D.; Matzinger, P.; Dunay, I.R.; et al. Ly6C (hi) Monocytes Provide a Link between Antibiotic-Induced Changes in Gut Microbiota and Adult Hippocampal Neurogenesis. Cell Rep. 2016, 15, 1945-1956. [CrossRef] [PubMed]

147. Medel-Matus, J.-S.; Shin, D.; Dorfman, E.; Sankar, R.; Mazarati, A. Facilitation of kindling epileptogenesis by chronic stress may be mediated by intestinal microbiome. Epilepsia Open 2018, 3, 290-294. [CrossRef]

148. Şafak, B.; Altunan, B.; Topçu, B.; Eren Topkaya, A. The gut microbiome in epilepsy. Microb. Pathog. 2020, 139, 103853. [CrossRef]

149. Dahlin, M.; Prast-Nielsen, S. The gut microbiome and epilepsy. EBioMedicine 2019, 44, 741-746. [CrossRef]

150. Aronica, E.; Bauer, S.; Bozzi, Y.; Caleo, M.; Dingledine, R.; Gorter, J.A.; Henshall, D.C.; Kaufer, D.; Koh, S.; Löscher, W.; et al. Neuroinflammatory targets and treatments for epilepsy validated in experimental models. Epilepsia 2017, 58, 27-38. [CrossRef]

151. Kobylarek, D.; Iwanowski, P.; Lewandowska, Z.; Limphaibool, N.; Szafranek, S.; Labrzycka, A.; Kozubski, W. Advances in the potential biomarkers of epilepsy. Front. Neurol. 2019, 10. [CrossRef] [PubMed] 
152. Sulis Sato, S.; Artoni, P.; Landi, S.; Cozzolino, O.; Parra, R.; Pracucci, E.; Trovato, F.; Szczurkowska, J.; Luin, S.; Arosio, D.; et al. Simultaneous two-photon imaging of intracellular chloride concentration and $\mathrm{pH}$ in mouse pyramidal neurons in vivo. Proc. Natl. Acad. Sci. USA 2017, 114, E8770-E8779. [CrossRef]

153. Vitaliti, G.; Pavone, P.; Mahmood, F.; Nunnari, G.; Falsaperla, R. Targeting inflammation as a therapeutic strategy for drugresistant epilepsies: An update of new immune-modulating approaches. Hum. Vaccines Immunother. 2014, 10, 868-875. [CrossRef] [PubMed]

154. Matsuo, M.; Sasaki, K.; Ichimaru, T.; Nakazato, S.; Hamasaki, Y. Increased IL-1 $\beta$ Production From dsRNA-stimulated Leukocytes in Febrile Seizures. Pediatr. Neurol. 2006, 35, 102-106. [CrossRef]

155. Jiang, J.; Ganesh, T.; Du, Y.; Quan, Y.; Serrano, G.; Qui, M.; Speigel, I.; Rojas, A.; Lelutiu, N.; Dingledine, R. Small molecule antagonist reveals seizure-induced mediation of neuronal injury by prostaglandin E2 receptor subtype EP2. Proc. Natl. Acad. Sci. USA 2012, 109, 3149-3154. [CrossRef]

156. Kino, T.; Hatanaka, H.; Miyata, S.; Inamura, N.; Nishiyama, M.; Yajima, T.; Goto, T.; Okuhara, M.; Kohsaka, M.; Aoki, H.; et al. Fk-506, A Novel Immunosuppressant Isolated From A Streptomyces Ii. Immunosuppressive Effect of Fk-506 In Vitro. J. Antibiot. 1987, 40, 1256-1265. [CrossRef] [PubMed]

157. Chwiej, J.; Janeczko, K.; Marciszko, M.; Czyzycki, M.; Rickers, K.; Setkowicz, Z. Neuroprotective action of FK-506 (tacrolimus) after seizures induced with pilocarpine: Quantitative and topographic elemental analysis of brain tissue. J. Biol. Inorg. Chem. 2010, 15, 283-289. [CrossRef]

158. Setkowicz, Z.; Ciarach, M. Neuroprotectants FK-506 and cyclosporin A ameliorate the course of pilocarpine-induced seizures. Epilepsy Res. 2007, 73, 151-155. [CrossRef] [PubMed]

159. Suzuki, K.; Omura, S.; Ohashi, Y.; Kawai, M.; Iwata, Y.; Tani, K.; Sekine, Y.; Takei, N.; Mori, N. Fk506 facilitates chemical kindling induced by pentylenetetrazole in rats. Epilepsy Res. 2001, 46, 279-282. [CrossRef]

160. Villani, F.; Avanzini, G. The use of immunoglobulins in the treatment of human epilepsy. Neurol. Sci. 2002, 23, S33-S37. [CrossRef]

161. Tan, T.H.-L.; Perucca, P.; O’Brien, T.J.; Kwan, P.; Monif, M. Inflammation, ictogenesis, and epileptogenesis: An exploration through human disease. Epilepsia 2021, 62, 303-324. [CrossRef]

162. Möller, T.; Bard, F.; Bhattacharya, A.; Biber, K.; Campbell, B.; Dale, E.; Eder, C.; Gan, L.; Garden, G.A.; Hughes, Z.A.; et al. Critical data-based re-evaluation of minocycline as a putative specific microglia inhibitor. Glia 2016, 64, 1788-1794. [CrossRef]

163. Bialer, M.; Johannessen, S.I.; Levy, R.H.; Perucca, E.; Tomson, T.; White, H.S. Progress report on new antiepileptic drugs: A summary of the Thirteenth Eilat Conference on New Antiepileptic Drugs and Devices (EILAT XIII). Epilepsia 2017, 58, 181-221. [CrossRef]

164. Chrzaszcz, M.; Venkatesan, C.; Dragisic, T.; Watterson, D.M.; Wainwright, M.S. Minozac treatment prevents increased seizure susceptibility in a mouse "two-hit" model of closed skull traumatic brain injury and electroconvulsive shock-induced seizures. $J$. Neurotrauma 2010, 27, 1283-1295. [CrossRef]

165. Maroso, M.; Balosso, S.; Ravizza, T.; Iori, V.; Wright, C.I.; French, J.; Vezzani, A. Interleukin-1 $\beta$ Biosynthesis Inhibition Reduces Acute Seizures and Drug Resistant Chronic Epileptic Activity in Mice. Neurotherapeutics 2011, 8, 304-315. [CrossRef]

166. Reichert, J.M. Marketed therapeutic antibodies compendium. MAbs 2012, 4, 413-415. [CrossRef]

167. Bakpa, O.D.; Reuber, M.; Irani, S.R. Antibody-associated epilepsies: Clinical features, evidence for immunotherapies and future research questions. Seizure 2016, 41, 26-41. [CrossRef]

168. DeSena, A.D.; Do, T.; Schulert, G.S. Systemic autoinflammation with intractable epilepsy managed with interleukin-1 blockade. J. Neuroinflamm. 2018, 15, 38. [CrossRef]

169. Cantarín-Extremera, V.; Jiménez-Legido, M.; Duat-Rodríguez, A.; García-Fernández, M.; Ortiz-Cabrera, N.V.; Ruiz-Falcó-Rojas, M.L.; González-Gutiérrez-Solana, L. Tocilizumab in pediatric refractory status epilepticus and acute epilepsy: Experience in two patients. J. Neuroimmunol. 2020, 340, 577142. [CrossRef]

170. Tognini, P. Gut microbiota: A potential regulator of neurodevelopment. Front. Cell. Neurosci. 2017, 11. [CrossRef]

171. Ansari, F.; Pourjafar, H.; Tabrizi, A.; Homayouni, A. The Effects of Probiotics and Prebiotics on Mental Disorders: A Review on Depression, Anxiety, Alzheimer, and Autism Spectrum Disorders. Curr. Pharm. Biotechnol. 2020, 21, 555-565. [CrossRef]

172. Abdellatif, B.; McVeigh, C.; Bendriss, G.; Chaari, A. The Promising Role of Probiotics in Managing the Altered Gut in Autism Spectrum Disorders. Int. J. Mol. Sci. 2020, 21, 4159. [CrossRef] [PubMed]

173. Gómez-Eguílaz, M.; Ramón-Trapero, J.L.; Pérez-Martínez, L.; Blanco, J.R. The beneficial effect of probiotics as a supplementary treatment in drug-resistant epilepsy: A pilot study. Benef. Microbes 2018, 9, 875-881. [CrossRef]

174. Cheung, K.A.K.; Peiris, H.; Wallace, G.; Holland, O.J.; Mitchell, M.D. The interplay between the endocannabinoid system, epilepsy and cannabinoids. Int. J. Mol. Sci. 2019, 20, 6079. [CrossRef] [PubMed]

175. White, C.M. A Review of Human Studies Assessing Cannabidiol's (CBD) Therapeutic Actions and Potential. J. Clin. Pharmacol. 2019, 59, 923-934. [CrossRef] [PubMed]

176. Wang, X.; Li, G.; Guo, J.; Zhang, Z.; Zhang, S.; Zhu, Y.; Cheng, J.; Yu, L.; Ji, Y.; Tao, J. Kv1.3 Channel as a Key Therapeutic Target for Neuroinflammatory Diseases: State of the Art and Beyond. Front. Neurosci. 2019, 13, 1393. [CrossRef]

177. Koh, S. Role of Neuroinflammation in Evolution of Childhood Epilepsy. J. Child Neurol. 2018, 33, 64-72. [CrossRef]

178. Veggiotti, P.; Pera, M.C.; Teutonico, F.; Brazzo, D.; Balottin, U.; Tassinari, C.A. Therapy of encephalopathy with status epilepticus during sleep (ESES/CSWS syndrome): An update. Epileptic Disord. 2012, 14, 1-11. [CrossRef]

179. Kelley, S.A.; Hartman, A.L. Metabolic Treatments for Intractable Epilepsy. Semin. Pediatr. Neurol. 2011, 18, 179-185. [CrossRef] 